\title{
Pengaruh Penerapan E-System Perpajakan danPengetahuan Perpajakan Wajib Pajak Pada Kepatuhan WPOP
}

\author{
Ni Putu Wina Purnama Dewi ${ }^{1}$ \\ Ni Luh Supadmi \\ ${ }^{1,2}$ Fakultas Ekonomi dan Bisnis Universitas Udayana (Unud), Bali, Indonesia \\ e-mail:winapurnama24@gmail.com
}

\begin{abstract}
ABSTRAK
E-Registration, e-Billing, dan e-Filling merupakan bagian dari e-System yang dikeluarkan oleh Direktorat Jenderal Pajak sebagai langkah modernisasi dalam pemenuhan kewajiban perpajakan oleh wajib pajak. Pengetahuan perpajakan merupakan salah satu kunci agar wajib pajak patuh pada kewajiban perpajakannya karena wajib pajak yang memiliki pengetahuan perpajakan paham akan peraturan akan dapat memenuhi kewajiban perpajakannya dengan baik. Penelitian ini bertujuan untuk mengetahui pengaruh penerapan e-System perpajakan dan pengetahuan perpajakan wajib pajak pada tingkat kepatuhan wajib pajak orang pribadi pada KPP Pratama Tabanan. Metode analisis data yang digunakan adalah analisis data secara kuantitatif dengan teknik analisis regresi linier berganda. Jenis data yang digunakan dalam penelitian ini merupakan data primer yang diperoleh dari jawaban wajib pajak orang pribadi yang terdaftar di KPP Pratama Tabanan. Hasil penelitian menunjukkan bahwa penerapan e-Registration, e-Billing, e-Filling, dan pengetahuan perpajakan wajib pajak berpengaruh positif terhadap kepatuhan wajib pajak orang pribadi di KPP Pratama Tabanan. Kata kunci: E-Registration, e-billing, e-filling, pengetahuan perpajakan wajib pajak, kepatuhan wajib pajak.
\end{abstract}

\begin{abstract}
E-Registration, e-Billing, and e-Filling are part of the e-System issued by the Directorate General of Taxation as a modernization step in fulfilling tax obligations by taxpayers. Knowledge of taxation is a key for taxpayers to comply with their tax obligations because taxpayers who have knowledge of taxation understand the rules so they can fulfill their tax obligations. This study aims to determine the effect of tax e-System implementation and taxpayer tax knowledge on the level of individual taxpayer compliance at the Tabanan Primary Tax Office. The data analysis method used is quantitative data analysis with multiple linear regression analysis techniques. This type of research is primary data obtained from the answers of individual taxpayers registered at the Tabanan Primary Tax Office, namely the answers to a series of questionnaire questions submitted by researchers. The results of this study indicate that the application of e-Registration, e-Billing, e-Filling, and knowledge of taxpayer taxation has a positive effect on individual taxpayer compliance at Tabanan Primary Tax Office.
\end{abstract}

Keywords: E-Registration, e-billing, e-filling, taxpayer tax knowledge, tax compliance.

\section{PENDAHULUAN}

Pajak merupakan penyumbang terbesar bagi penerimaan pemerintah pusat dan pemerintah daerah. Penerimaan dari sektor pajak merupakan salah satu sumber utama yang diandalkan pemerintah dalam membiayai pembangunan serta 
Ni Putu Wina Purnama Dewi dan Ni Luh Supadmi. Pengaruh ...

pengeluaran-pengeluaran lainnya. Santika(2014), menyatakan pajak merupakan kekayaan potensial yang dimiliki oleh setiap negaratermasuk Indonesia.

Untuk mengukur kinerja perpajakan diseluruh dunia digunakantax revenue to GDP ratio, atau sering dikenal istilah tax ratio. Tax ratio yaitu formula untuk mengukur kinerja perpajakan dengan membandingkan antara penerimaan perpajakan dan Pendapatan Domestik Bruto (PDB) dalam kurun waktu tertentu, umumnya satu tahun (www.pajak.go.id). Sejak tahun 2015 hingga 2017, tax ratio Indonesia hanya berkisar di angka 10 persen,tax ratio tahun 2017 berada di level 10,8 persen dengan total $\mathrm{PDB}$ nominal sebesar $\mathrm{Rp} 13.588,8$ triliun dan pertumbuhan ekonomi 5,07 persen (BPS, 2018). Tahun 2018, tax ratio hanya ditarget sebesar 10,9 persen. Artinya untuk menembus level 11 persen masih sulit ditengah tingginya tax ratio Negara lain. Negara-negara diwilayah Asia tenggara memiliki tax ratio yang lebih tinggi dari Indonesia seperti Malaysia 14,4 persen, Filipina 13,67 persen, Singapura 14,29 persen. Tax ratio Indonesia masih lebih rendah dibanding nilai rata-rata tax revenue to GDP ratio di dunia sebesar 15,06 persen (www.pajak.go.id).Jika kebutuhan belanja sekitar 15-16 persen dari total PDB, idealnya tax ratio di Indonesia harus mendekati angka tersebut untuk mendorong fiscal sustainability dan menjamin defisit tetap terkendali.

Di Indonesia pemungutan pajak menggunakan self assessment system. Self assessment system adalah suatu sistem pemungutan pajak yang memberi wewenang kepada wajib pajak untuk menentukan sendiri besarnya pajak yang terutang (Mardiasmo, 2016:7). Kepatuhan dan kesadaran wajib pajak menjadi faktor yang sangat penting untuk mencapai keberhasilan penerimaan pajak 
(Arum, 2012). Dengan self assessment system ini, diharapkan wajib pajak mempunyai pemahaman terhadap peraturan perpajakan. Kepatuhan wajib pajak adalah upaya wajib pajak sebagai warga negara dalam memenuhi kewajiban perpajakannya secara sukarela sehingga dapat meningkatkan penerimaan pajak dan memberikan kontribusi bagi pembangunan negara. Kepatuhan wajib pajak menurut Rahayu (2010)adalah keadaan dimana wajib pajak memenuhi semua kewajiban perpajakan dan melaksanakan hak perpajakannya. Kepatuhan wajib pajak merupakan faktor yang sangat penting bagi peningkatan penerimaan pajak. Fitria (2010), menyatakankurangnya kesadaran Wajib Pajak merupakan faktor dari melemahnya self assessment system yang akan berdampak pada penurunan pajak. Kesadaran dari wajib pajak untuk membayar pajak adalah hal yang paling dibutuhkan dalam pemungutan pajak. Seringkali wajib pajak tidak taat pajak sebab kesulitan dari proses pelaporan dan pembayaran. Perkembangan teknologi yang semakin maju dapat menjawab kesulitankesulitan yang dikeluhkan wajib pajak tersebut dengan menerapkan $e$-system perpajakan.

Menurut Heenkenda(2016), ketidakpatuhan membayar pajak dianggap sebagai tantangan serius yang dapat melemahkan administrasi perpajakan dan kinerja penerimaan pajak. Persoalan mengenai kepatuhan wajib pajak telah menjadi persoalan yang penting di Indonesia, sebab jika Wajib Pajak tidak patuh maka dapat menimbulkan keinginan untuk melakukan tindakan penghindaran, pengelakan dan pelalaian pajak yang pada akhirnya akan merugikan negara yaitu berkurangnya penerimaan pajak. Kepatuhan Wajib Pajak dapat dipengaruhi oleh 
Ni Putu Wina Purnama Dewi dan Ni Luh Supadmi. Pengaruh ...

dua faktor yaitu faktor internal dan faktor eksternal. Faktor internal merupakan faktor yang berasal dari diri Wajib Pajak sendiri dan berhubungan dengan karakteristik individu dalam menjalankan kewajiban perpajakannya. Sedangkan faktor eksternalnya adalah faktor yang berasal dari luar diri Wajib Pajak, seperti situasi dan lingkungan di sekitar Wajib Pajak. Kepatuhan wajib pajak bisa dipengaruhi oleh faktor eksternal seperti diterapkannya $e$-System perpajakan yang dikeluarkan oleh Direktorat Jenderal Pajak dan faktor internal yaitu pengetahuan perpajakan dari Wajib Pajak itu sendiri.

Direktorat Jenderal Pajak (DJP) terus berupaya untuk melakukan inovasi dibidang pembaharuan sistem perpajakan sebagai bentuk perkembangan sistem perpajakan dengan meningkatkan kualitas pelayanan sehingga penerimaan negara dari sektor perpajakan juga akan meningkat. DJP telah mengeluarkan sistem administrasi perpajakan yang memanfaatkan teknologi yaitu e-System atau Electronic System. Pada awal tahun 2005 sebagai langkah awal mewujudkan modernisasi sistem perpajakan di Indonesia dikeluarkan e-system perpajakan. Adanya e-System ini diharapkan wajib pajak dapat lebih mudah dalam proses pelaporan serta pembayaran. E-System yang diluncurkan berupa $e$-Registration, $e$ SPT dane-FIN, e-Filling, e-Billing, e-faktur, e-Form, dan e-Report. Dalampenelitian ini hanya meneliti tiga dari e-system yang dikeluarkan oleh Direktorat Jenderal Pajak yaitu e-Registration, e-Billing, dan e-Filling.

E-registration atau sistem pendaftaran Wajib Pajak secara online adalah sistem aplikasi bagian dari sistem informasi perpajakan dilingkungan DJP dengan berbasis perangkat keras dan perangkat lunak yang dihubungkan oleh perangkat 
komunikasi data yang digunakan untuk mengelola proses pendaftaran Wajib Pajak. Sistem ini terbagi dua bagian, yaitu sistem yang dipergunakan oleh wajib pajak yang berfungsi sebagai sarana pendaftaran Wajib pajak secara online dan sistem yang dipergunakan oleh Petugas Pajak yang berfungsi untuk memproses pendaftaran Wajib Pajak.

E-billing merupakan pembaharuan sistem perpajakan menggunakan kode billing yang secara elektronik dapat melakukan pembayaran pajak. Kode Billing itusendiri merupakan kode identifikasi atas suatu jenis transaksi pajak yang akan dilakukan oleh wajib Pajak. Sistem billing ini menerbitkan sebuah kode billing yang dapat digunakan secara elektronik untuk melakukan pembayaran atau penyetoran penerimaan negara, dengan tidak harus menggunakan surat setoran pajak (SSP), surat setoran bukan pajak (SSBP), dan surat setoran pengembalian belanja (SSPB) manual, yang digunakan e-Billing DJP.

E-filling menurut Peraturan Direktorat Jenderal Pajak Nomor PER1/PJ/2014merupakan cara menyampaikan secara elektronik mengenai surat pemberitahuan (SPT) secara online dan real time yang diakses pada website resmi Direktorat Jenderal Pajak (www.pajak.go.id). Dengan adanya e-Fillingini diharapkan kepatuhan wajib pajak dalam melaporkan SPT dapat ditingkatkan. E-Spt dan $e$-Fin adalah alat kelengkapan dari e-Filling.

E-Form adalah penyampaian SPT dengan mengisi formulir elektronik. Jika pada $e$-filling Wajib Pajak harus selalu terkoneksi jaringan internet maka isian pada $e$-form tidak harus terkoneksi internet, pengguna cukup konek internet hanya pada saat akan mengambil formulir dan pada saat mengunggahnya saja 
Ni Putu Wina Purnama Dewi dan Ni Luh Supadmi. Pengaruh ...

(upload). Sementara untuk pengguna $e$-Spt, pengguna harus memasang aplikasi $e$ Spt sebanyak jenis pajak yang mau dilaporkan. Sehingga e-Form hadir sebagai alternatif lain yang mana 1 viewer bisa digunakan untuk mengisi berbagai formulir elektronik dari berbagai jenis pajak, dan formulir yang diisi tampilannya mirip dengan formulir SPT versi hardcopy/kertas.E-Form tidak diteliti dalam penelitian ini karena sudah diteliti $e$-Filling yang memiliki fungsi sama dengan $e$ Formyaitu sebagai sarana penyampaian SPT.

E-Reporting adalah sarana yang tersedia di DJP Online untuk melaporkan penempatan harta dalam negeri dan/ atau formulir laporan penempatan harta repatriasi. Menu e-Reporting hanya tersedia bagi wajib pajak yang telah berpartisipasi dalam amnesti pajak.E-Reporting tidak diteliti dalam penelitian ini karena $e$-Reporting hanya diperuntukkan bagi wajib pajak yang telah melalukan tax amnesty sedangkan tidak semua wajib pajak harus melakukan tax amnesty. Tax amnesty hanya dilakukan oleh wajib pajak yang masih memiliki harta yang selama ini tidak dilaporkan.

Pengetahuan perpajakan merupakan salah satu faktor potensial bagi pemerintah untuk meningkatkan kepatuhan wajib pajak dalam memenuhi kewajiban perpajakannya. Tanpa adanya pengetahuan tentang pajak dan manfaatnya tidak mungkin orang secara ikhlas membayar pajak (Susilawati \& Budiartha, 2013). Apabila wajib pajak tidak memiliki pengetahuan perpajakan, maka akan mengalami kesulitan dalam mendaftarkan diri, mengisi SPT, dan menyetorkan pajaknya (Handayani, 2013). Pengetahuan perpajakan merupakan pemahaman Wajib Pajak mengenai hukum, undang-undang, tata cara perpajakan 
yang benar. Wajib pajak yang memiliki pengetahuan tentang pajak yang baik akan dapat memperkecil adanya tax evation(Witono, 2008).

Penelitian yang dilakukan oleh Ersania \& Merkusiwati (2018) menyebutkan bahwa penerapan e-registration berpengaruh positif terhadap kepatuhan wajib pajak orang pribadi, penerapan e-Billing berpengaruh positif terhadap kepatuhan wajib pajak orang pribadi, dan penerapan e-Filling berpengaruh positif terhadap kepatuhan wajib pajak orang pribadi. Penelitian yang dilakukan oleh Pratamiet et al. (2017) menyebutkan bahwa Penerapan e-System berpengaruh positif terhadap kepatuhan wajib pajak orang pribadi. Penelitian yang dilakukan oleh Putra (2015) juga menyebutkan bahwa penerapan Sistem Administrasi $e$-Registration, $e$-Spt, dan $e$-Filling berpengaruh terhadap tingkat Kepatuhan Wajib Pajak. Namun berbeda dengan hasil penelitian yang dilakukan oleh Mahyudin(2015)yang memberikan bukti empiris bahwa penerapan e-SPT tidak berpengaruh signifikan terhadap kepatuhan wajib pajak. Penelitian yang dilakukan oleh Azizah (2014) juga menunjukkan bahwa e-Registration dan $e$ Filling tidak berpengaruh signifikan terhadap kepatuhan wajib pajak. Beberapa penelitian terdahulu menunjukkan hasil yang tidak konsisten, untuk itu peneliti ingin meneliti kembali pengaruh penerapan e-system terhadap tingkat kepatuhan wajib pajak orang pribadi.

Penelitian yang dilakukan oleh Palil \& Mustapha (2016) dan Kesumasari \& Suardana (2018), menyatakan bahwa ketika seseorang wajib pajak memiliki pengetahuan perpajakan yang baik, sikap terhadap kewajiban pajak akan lebih positif dan dapat meningkatkan kepatuhan dan mengurangi kecurangan 
menghindari pajak. Sejalan dengan penelitian Putri \& Suandy (2015) dan Ulfa \& Ratnawati (2015) menunjukkan bahwa pengetahuan perpajakan memberikan pengaruh signifikan terhadap kepatuhan wajib pajak. Namun berbeda dengan hasil penelitian Hardiningsih \& Yulianawati (2011) bahwa pengetahuan peraturan perpajakan tidak berpengaruh terhadap kemauan membayar pajak. Peneliti ingin meneliti kembali variabel tersebut karena ada ketidakkonsistenan hasil penelitian yang terdahulu.

Target kepatuhan pajak nasional yang diharapkan dapat dicapai adalah 72,5 persen untuk masing-masing KPP berdasarkan Surat Edaran Nomor SE07/PJ/2016 mengenai penetapan Target dan Strategi Pencapaian Rasio Kepatuhan Wajib Pajak tahun 2016. Penelitian ini dilakukan di KPP Pratama Tabanan, dipilih sebagai lokasi penelitian sebab KPP Pratama Tabanan memiliki jumlah WPOP terbesar kedua setelah KPP Pratama Gianyar di wilayah Kanwil DJP Bali dan KPP Pratama Tabanan mewilayahi dua kabupaten yaitu Tabanan dan Jembrana dan merupakan KPP terakhir yang dibentuk di Kanwil DJP Bali. KPP Pratama Tabanan memiliki rasio kepatuhan pajak yang cenderung menurun.Tingkat kepatuhan wajib pajak orang pribadi di KPP Pratama Tabanan disajikan pada Tabel1 berikut.

Tabel 1.

Tingkat Kepatuhan Wajib Pajak Orang Pribadi di KPP Pratama Tabanan Tahun 2013-2017

\begin{tabular}{cccccc}
\hline Tahun & $\begin{array}{c}\text { WPOP } \\
\text { Terdaftar }\end{array}$ & $\begin{array}{c}\text { WPOP } \\
\text { Efektif }\end{array}$ & $\begin{array}{c}\text { WPOP yang } \\
\text { menyampaikan } \\
\text { SPT }\end{array}$ & $\begin{array}{c}\text { WPOP yang } \\
\text { menyampaikan SPT } \\
\text { secara online }\end{array}$ & $\begin{array}{c}\text { Rasio } \\
\text { Kepatuhan }\end{array}$ \\
\hline 2013 & 84.689 & 60.541 & 39.151 & 8 & $64,67 \%$ \\
2014 & 92.196 & 67.825 & 42.351 & 3.746 & $62,44 \%$ \\
2015 & 100.169 & 75.621 & 37.703 & 9.079 & $49,86 \%$ \\
2016 & 107.973 & 83.243 & 45.849 & 35.283 & $55,08 \%$ \\
2017 & 116.865 & 92.030 & 42.922 & 36.294 & $46,64 \%$ \\
\hline Sumber: KPP Pratama Tabanan, 2018 & & &
\end{tabular}


Berdasarkan Tabel 1, dapat dilihat bahwa WPOP efektif yang terdaftar di KPP Tabanan dari tahun 2013-2017 mengalami peningkatan, namun rasio kepatuhan pajak dari tahun 2013-2017 di KPP Pratama Tabanan mengalami fluktuasi yang cenderung menurun. Rasio kepatuhan wajib pajak di KPP Pratama Tabanan pada tahun 2017 yaitu sebesar 46,64 persen masih jauh di bawah target kepatuhan pajak nasional yang ditetapkan oleh Direktorat Jenderal Pajak sesuai dengan Surat Edaran Nomor SE-07/PJ/2016, yaitu sebesar 72,5 persen. Berdasarkan Tabel 1, dapat dilihat juga bahwa jumlah wajib pajak orang pribadi yang melaporkan kewajiban perpajakan menggunakan e-System di KPP Pratama Tabanan dari tahun 2013-2017 mengalami peningkatan namun rasio kepatuhan wajib pajak pada KPP Pratama Tabanan mengalami fluktuasi yang cenderung menurun.

Menurut teori atribusi, perilaku seseorang ditentukan oleh kombinasi antara kekuatan internal dan kekuatan eksternal. Salah satu kekuatan eksternal atau faktor-faktor yang berasal dari luar wajib pajak dalam penelitian ini adalah $e$ registration. Atribusi merupakan salah satu proses pembentukan kesan dan Acceptance Model yang digunakan untuk melihat bagaimana suatu sistem teknologi dapat mempengaruhi pemakai. MenurutErsania \& Merkusiwati(2018), e-Registration berpengaruh positif terhadap kepatuhan wajib pajak orang pribadi pada Kantor Pelayanan Pajak Pratama Tabanan. Menurut Putra(2015)menyatakan e-Registration berpengaruh positif terhadap kepatuhan wajib pajak. Sistem ini dipergunakan oleh wajib pajak yang berfungsi sebagai sarana pendaftaran Wajib 
Ni Putu Wina Purnama Dewi dan Ni Luh Supadmi. Pengaruh ...

pajak secara online. Berdasarkan uraian tersebut, dapat diajukan hipotesis penelitian sebagai berikut.

$\mathrm{H}_{1}$ : Penerapan e-Registration berpengaruh positif pada kepatuhan wajib pajak orang pribadi pada Kantor Pelayanan Pajak Pratama Tabanan

TAM merupakan model yang menjelaskan perilaku penerimaan teknologi.

Dalam model TAM digambarkan bahwa persepsi kemudahan berpengaruh terhadap sikap. Sedangkan niat merupakan suatu fungsi dasar penentu yang berhubungan dengan faktor pribadi. Seseorang yang memiliki perasaan positif terhadap penggunaan teknologi akan memiliki niat untuk menggunakan teknologi di waktu yang akan datang. MenurutPusparesmi(2016), menyatakan bahwa penggunaan $e$-Billing berpengaruh positif terhadap kepatuhan wajib pajak. Sistem billing ini menerbitkan sebuah kode billing yang dapat digunakan secara elektronik untuk melakukan pembayaran atau penyetoran penerimaan negara, dengan tidak harus menggunakan surat setoran pajak (SSP), surat setoran bukan pajak (SSBP), dan surat setoran pengembalian belanja (SSPB) manual akan meningkatkan kepatuhan wajib pajak. Berdasarkan uraian tersebut, maka diajukan hipotesis penelitian sebagai berikut.

$\mathrm{H}_{2}$ : Penerapan $e$-Billing berpengaruh positif pada kepatuhan wajib pajak orang pribadi pada Kantor Pelayanan Pajak Pratama Tabanan

Teori TAM beragumentasi bahwa penerimaan individu terhadap sistem teknologi informasi ditentukan oleh dua konstruk yaitu persepsi kegunaan (perceived usefulness) dan persepsi kemudahan penggunaan (perceived ease of use). Persepsi kegunaan adalah manfaat yang diyakini dapat diperoleh individu apabila menggunakan teknologi informasi. Persepsi kegunaan memiliki hubungan 
terhadap sikap terhadap penggunaan. Sikap terhadap pengguna dapat didefinisikan sebagai perasaan-perasaan positif atau negatif dari seseorang jika harus melakukan perilaku yang akan ditentukan. Seseorang yang merasa penggunaan sistem bermanfaat atau menguntungkan akan memiliki sikap atau perasaan positif terhadap penggunaan sistem tersebut. Penyampaian surat pemberitahuan (SPT) secara elektronik dapat memberikan dorongan tersendiri bagi wajib pajak karena mereka tidak perlu datang ke KPP untuk memenuhi kewajiban perpajakannya. MenurutPutra(2015), menyatakan bahwa penerapan $e$ Filling berpengaruh terhadap tingkat kepatuhan wajib pajak. Hal ini menunjukkan bahwa tingkat kepatuhan wajib pajak timbul karena adanya $e$-Filling yang merupakan cara menyampaikan secara elektronik mengenai surat pemberitahuan (SPT) secara online dan real time. Berdasarkan uraian tersebut, maka diajukan hipotesis penelitian sebagai berikut.

$\mathrm{H}_{3}$ : Penerapan $e$-Filling berpengaruh positif pada kepatuhan wajib pajak orang pribadi pada Kantor Pelayanan Pajak Pratama Tabanan.

Berdasarkan teori atribusi, pengetahuan perpajakan wajib pajak merupakan penyebab dari dalam yang dapat mempengaruhi tingkat kepatuhan wajib pajak. Pemahaman wajib pajak sangat diperlukan untuk meningkatkan kepatuhan wajib pajak. Menurut penelitian Syahril (2013), Astuti(2015) serta Damajanti \& Karim (2017), mengungkapkam bahwa pengetahuan perpajakan wajib pajak berpengaruh positif dan signifikan terhadap tingkat kepatuhan wajib pajak. Tingkat pemahaman wajib pajak mengenai perpajakan menjadi hal penting dalam menentukan sikap perpajakan dan perilaku wajib pajak dalam memenuhi 
Ni Putu Wina Purnama Dewi dan Ni Luh Supadmi. Pengaruh ...

kewajibannya. Berdasarkan pemaparan diatas, maka dapat dirumuskan hipotesis sebagai berikut.

$\mathrm{H}_{4}$ : Pengetahuan perpajakan wajib pajak berpengaruh positif pada tingkat kepatuhan wajib pajak orang pribadi di KPP Pratama Tabanan.

\section{METODE PENELITIAN}

Penelitian ini dilakukan di Kantor Pelayanan Pajak (KPP) Pratama Tabanan yang beralamat di jalan Gatot Subroto No.2, Banjar Anyar, Kediri, Kabupaten Tabanan, Bali. KPP Pratama Tabanan dipilih sebagai wilayah penelitian, sebab jumlah WPOP terdaftar mengalami peningkatan namun rasio kepatuhan wajib pajak di KPP Pratama Tabanan pada tahun 2013-2017 mengalami fluktuasi namun cenderung menurun. Rasio kepatuhan wajib pajak di KPP Pratama Tabanan pada tahun 2017 yaitu sebesar 46,64 persen masih jauh di bawah target kepatuhan pajak nasional yang ditetapkan oleh Direktorat Jenderal Pajak sesuai dengan Surat Edaran Nomor SE-07/PJ/2016, yaitu sebesar 72,5 persen.

Populasi dalam penelitian ini adalah sebanyak 92.030 Wajib Pajak Orang Pribadi efektif pada Kantor Pelayanan Pajak Pratama Tabanan tahun 2017.Metode yang digunakan untuk menentukan jumlah sampel Wajib Pajak Orang Pribadi adalah menggunakan rumus Slovin seperti berikut :

$$
\mathrm{n}=\frac{\mathrm{N}}{\left(1+\mathrm{N} \cdot \mathrm{e}^{2}\right)}
$$

Keterangan :

$\mathrm{n}=$ Jumlah sampel

$\mathrm{N}=$ Jumlah populasi

$\mathrm{e}=$ Tingkat kesalahan yang ditoleransi $(0,1)$ 
Perhitungan sampel :

$$
\mathrm{n}=\frac{92.030}{\left(1+92.030 \cdot(0,1)^{2}\right)}
$$

$\mathrm{n}=99,89$ dibulatkan menjadi 100

Penelitian ini menggunakan analisis regresi linear berganda, karena terdapat satu variabel dependen dan beberapa variabel independen. Model regresi linear berganda ditunjukkan oleh persaamaan regresi berikut.

$$
Y=\alpha+\beta_{1} X_{1}+\beta_{2} X_{2}+\beta_{3} X_{3}+\beta_{4} X_{4}+\varepsilon
$$

Keterangan :

$$
\begin{array}{ll}
\mathrm{Y} & =\text { tingkat kepatuhan wajib pajak } \\
\alpha & =\text { konstanta } \\
\beta & =\text { koefisien regresi variabel } \mathrm{X}_{1}-\mathrm{X}_{4} \\
\mathrm{X}_{1} & =\text { e-registration } \\
\mathrm{X}_{2} & =\mathrm{e} \text {-billing } \\
\mathrm{X}_{3} & =e \text {-filling } \\
\mathrm{X}_{4} & =\text { pengetahuan Perpajakan Wajib Pajak } \\
\varepsilon & =\text { error }
\end{array}
$$

\section{HASIL DAN PEMBAHASAN}

Statistik deskriptif berhubungan dengan pengumpulan dan peringkat data yang menggambarkan karakteristik dari masing-masing variabel yang digunakan dalam penelitian ini. Analisis ini berguna untuk menjelaskan karakteristik dari variabel penelitian diantaranya nilai rata-rata (mean), nilai ekstrim yaitu nilai minimum dan nilai maksimum, standar deviasi serta $\mathrm{N}$ yang merupakan jumlah responden dalam penelitian ini. Hasil dari deskriptif tersebut dapat dilihat pada Tabel 2 berikut. 
Tabel 2.

Statistik Deskriptif

\begin{tabular}{lccccc}
\hline & $\mathrm{N}$ & Minimum & Maximum & Mean & Std. Deviation \\
\hline e-Registration & 100 & 5 & 16 & 10,83 & 2,301 \\
e-Billing & 100 & 8 & 23 & 16,94 & 3,031 \\
e-Filling & 100 & 22 & 56 & 36,94 & 6,207 \\
Pengetahuan Perpajakan & 100 & 10 & 19 & 15,99 & 1,806 \\
Kepatuhan Wajib Pajak & 100 & 15 & 28 & 21,27 & 2,704 \\
\hline
\end{tabular}

Sumber:Data diolah, 2018

Tabel 2 menunjukkan bahwa responden wajib pajak orang pribadi dalam penelitian ini adalah sebanyak 100 kuesioner. Variabel e-Registration $\left(\mathrm{X}_{1}\right)$ memiliki nilai minimum sebesar 5 , nilai maksimum sebesar 16 , mean sebesar 10,83 yang apabila dibagi dengan 4 item pertanyaan akan menghasilkan nilai sebesar 2,7075 yang artinya rata-rata responden memberikan skor 3 ditiap item pertanyaan e-Registration. Standar deviasi sebesar 2,301, menunjukkan bahwa standar penyimpangan data terhadap nilai rata-ratanya sebesar 2,301 .

Variabel e-Billing $\left(\mathrm{X}_{2}\right)$ memiliki nilai minimum sebesar 8 , nilai maksimum sebesar 23, mean sebesar 16,94 yang apabila dibagi dengan 6 item pertanyaan akan menghasilkan nilai sebesar 2,8233 yang artinya rata-rata responden memberikan skor 3 ditiap item pertanyaan e-Billing. Standar deviasi sebesar 3,031, menunjukkan bahwa standar penyimpangan data terhadap nilai rata-ratanya sebesar 3,031.

Variabel e-Filling $\left(\mathrm{X}_{3}\right)$ memiliki nilai minimum sebesar 22 , nilai maksimum sebesar 56, mean sebesar 36,94 yang apabila dibagi dengan 14 item pertaanyaan akan menghasilkan nilai sebesar 2,6385 yang artinya rata-rata responden memberikan skor 3 di tiap item pertanyaan e-Filling. Standar deviasi sebesar 6,207, menunjukkan bahwa standar penyimpangan data terhadap nilai rata-ratanya sebesar 6,207. 
Variabel Pengetahuan Perpajakan Wajib Pajak $\left(\mathrm{X}_{4}\right)$ memiliki nilai minimum sebesar 10, nilai maksimum sebesar 19, mean sebesar 15,99 yang apabila dibagi dengan 6 item pertanyaan akan menghasilkan nilai sebesar 2,665 yang artinya rata-rata responden memberikan skor 3 di tiap item pertanyaan pengetahuan perpajakan wajib pajak. Standar deviasi sebesar 1,806 , menunjukkan bahwa standar penyimpangan data terhadap nilai rata-ratanya sebesar 1,806.

Variabel Kepatuhan Wajib Pajak (Y) memiliki nilai minimum sebesar 15, nilai maksimum sebesar 28, mean sebesar 21,27 yang apabila dibagi dengan 7 item pertanyaan akan menghasilkan nilai sebesar 3,038 yang artinya rata-rata responden memberikan skor 3 di tiap item pertanyaan kepatuhan wajib pajak. Standar deviasi sebesar 2,704, menunjukkan bahwa standar penyimpangan data terhadap nilai rata-ratanya sebesar 2,704.

Hasil analisis regresi liniear berganda disajikan pada Tabel 3 berikut.

Tabel 3.

Hasil Uji Analisis Regresi Linear Berganda

\begin{tabular}{lccccc}
\hline Model & \multicolumn{2}{c}{$\begin{array}{l}\text { Unstandardized } \\
\text { Coefficients }\end{array}$} & $\begin{array}{c}\text { Standardized } \\
\text { Coefficients }\end{array}$ & $\mathrm{t}$ & Sig. \\
& $\mathrm{B}$ & Std. Error & Beta & & \\
\hline (Constant) & 7.780 & 1.290 & & 6.029 & .000 \\
e-Registration & .421 & .082 & .359 & 5.133 & .000 \\
e-Billing & .187 & .057 & .209 & 3.261 & .002 \\
e-Filling & .208 & .035 & .477 & 5.941 & .000 \\
Pengetahuan Perpajakan & .298 & .120 & .297 & 2.473 & .016 \\
\hline Sumber: Data diolah, 2018 & & & & &
\end{tabular}

Berdasarkan Tabel 3 dapat dibuat rumus persamaan regresi sebagai berikut:

$$
Y=7,780+0,421 X_{1}+0,187 X_{2}+0,208 X_{3}+0,298 X_{4}
$$


Ni Putu Wina Purnama Dewi dan Ni Luh Supadmi. Pengaruh ...

Nilai konstanta $(\alpha)$ sebesar 7,780 apabila e-Registration $\left(\mathrm{X}_{1}\right)$, e-Billing $\left(\mathrm{X}_{2}\right)$, e-Filling $\left(\mathrm{X}_{3}\right)$, dan pengetahuan perpajakan $\left(\mathrm{X}_{4}\right)$ sama dengan nol, maka kepatuhan wajib pajak (Y) meningkat sebesar 7,780.

Nilai koefisien $\left(\beta_{1}\right)$ sebesar 0,421 menunjukkan apabila e-Registration $\left(\mathrm{X}_{1}\right)$ mengalami peningkatan, maka kepatuhan wajib pajak akan cenderung meningkat. Ini berarti jika penerapan $e$-Registration meningkat, maka wajib pajak akan semakin patuh dalam memenuhi kewajiban perpajakannya.

Nilai koefisien $\left(\beta_{2}\right)$ sebesar 0,187 menunjukkan apabila e-Billing $\left(\mathrm{X}_{2}\right)$ mengalami peningkatan, maka kepatuhan wajib pajak akan cenderung meningkat. Ini berarti jika penerapan e-Billing meningkat, maka wajib pajak akan semakin patuh dalam memenuhi kewajiban perpajakannya.

Nilai koefisien $\left(\beta_{3}\right)$ sebesar 0,208 menunjukkan apabila e-Filling $\left(\mathrm{X}_{3}\right)$ mengalami peningkatan, maka kepatuhan wajib pajak akan cenderung meningkat. Ini berarti jika penerapan e-Filling meningkat, maka wajib pajak akan semakin patuh dalam memenuhi kewajiban perpajakannya.

Nilai koefisien $\left(\beta_{4}\right)$ sebesar 0,298 menunjukkan apabila pengetahuan perpajakan $\left(\mathrm{X}_{4}\right)$ mengalami peningkatan, maka kepatuhan wajib pajak akan cenderung meningkat. Ini berarti jika semakin meningkat pengetahuan perpajakan wajib pajak, maka wajib pajak akan semakin patuh dalam memenuhi kewajiban perpajakannya.

Koefisen Determinasi $\left(\mathrm{R}^{2}\right)$ digunakan untuk mengukur seberapa besar kemampuan model dalam menerangkan variasi variabel dependen. Nilai $\left(\mathrm{R}^{2}\right)$ yang kecil berarti kemampuan variabel-variabel independen dalam menjelaskan variasi 
variabel dependen terbatas, sedangkan apabila nilai koefisien determinasi tinggi berarti variabel independen mampu sepenuhnya menjelaskan variasi dari variabel dependen. Hasil koefisien determinasi disajikan dalam Tabel 4 berikut.

Tabel 4.

Hasil Koefisien Determinasi

\begin{tabular}{ccccc}
\hline Model & $\mathrm{R}$ & $\mathrm{R}$ Square & Adjusted R Square & $\begin{array}{c}\text { Std. Error of the } \\
\text { Estimate }\end{array}$ \\
\hline 1 & $.875^{\mathrm{a}}$ & .766 & .756 & 1.336 \\
\hline Sumber : Data diolah, 2018 & & &
\end{tabular}

Besarnya nilai Adjusted R square adalah sebesar 0,756 yang artinya sebesar 75,6 persen variasi kepatuhan wajib pajak dipengaruhi oleh $e$ Registration, e-Billing, e-Filling, dan pengetahuan perpajakan sedangkan sisanya sebesar 24,4 persen dipengaruhi oleh faktor lain yang tidak dimasukkan ke dalam model penelitian.

Pengujian ini dilakukan untuk mengetahui apakah model penelitian layak digunakan sebagai alat analisis. Hasil uji F disajikan dalam Tabel 5 berikut.

Tabel 5.

Hasil uji F

\begin{tabular}{ccccccc}
\hline Model & & Sum of Squares & Df & Mean Square & F & Sig. \\
\hline \multirow{4}{*}{1} & Regression & 554.090 & 4 & 138.523 & 77.583 & $.000^{\mathrm{b}}$ \\
& Residual & 169.620 & 95 & 1.785 & & \\
& Total & 723.710 & 99 & & & \\
\hline
\end{tabular}

Sumber : Data diolah, 2018

Berdasarkan Tabel 5, nilai signifikansi $\mathrm{F}$ adalah sebesar 0,000 lebih kecil dari $0,05(\mathrm{~F}<\alpha)$ yang berarti model penelitian layak digunakan untuk menganalisis pengaruhe-Registration $\left(\mathrm{X}_{1}\right)$, e-Billing $\left(\mathrm{X}_{2}\right)$,e-Filling $\left(\mathrm{X}_{3}\right)$, dan pengetahuan perpajakan $\left(\mathrm{X}_{4}\right)$ pada kepatuhan wajib pajak $(\mathrm{Y})$.

Uji t dilakukan untuk menguji hipotesis yaitu variabel bebas terhadap variabel terikat. Level of significant $(\alpha)$ yang digunakan adalah $5 \%(0,05) . \mathrm{H}_{\mathrm{i}}$ 
Ni Putu Wina Purnama Dewi dan Ni Luh Supadmi. Pengaruh ...

diterima jika $p$-value $<\alpha=0,05$. Berdasarkan Tabel 6 hasil pengujian pengaruh masing-masing variabel bebas terhadap variabel terikat dapat dijabarkan seperti berikut.

Variabel e-Registration memiliki nilai koefisien beta positif sebesar 0,421 dengan nilai signifikansi sebesar 0,000. Nilai koefisien beta $>0$ dan nilai signifikansi $<0,05$ mengindikasikan bahwa e-Registration berpengaruh positif dan signifikan terhadap kepatuhan wajib pajak.Hal ini menunjukkan bahwa hipotesis pertama dalam penelitian ini diterima yaitu, e-Registration berpengaruh positif pada kepatuhan wajib pajak orang pribadi di Kantor Pelayanan Pajak Pratama Tabanan, artinya semakin baik penerapan e-Registration, maka kepatuhan wajib pajak juga akan semakin meningkat.

Adanya e-Registration mempermudah Wajib Pajak dalam melakukan proses pendaftaran sebagai wajib pajak. TeoriTechnology Acceptance Model (TAM) menjelaskan bahwa bagaimana pengguna teknologi menerima dan menggunakan teknologi tersebut dalam pekerjaan individual pengguna. Jika $e$ Registration ini diterima dan diterapkan secara baik oleh Wajib Pajak yang terdaftar di KPP Pratama Tabanan, maka kepatuhan Wajib Pajak akan meningkat.

Hasil penelitian ini didukung oleh penelitian yang dilakukan Putra (2015) yang meneliti tentang pengaruh penerapan Sistem Administrasi e-Registration, $e$ $S P T$, dan e-Filling terhadap kepatuhan wajib pajak. Hasil penelitian tersebut menunjukkane-Registration berpengaruh signifikan terhadap kepatuhan wajib pajak orang pribadi. 
Variabel e-Billing memiliki nilai koefisien beta positif sebesar 0,187 dengan nilai signifikansi sebesar 0,002. Nilai koefisien beta $>0$ dan nilai signifikansi $<0,05$ mengindikasikan bahwa $e$-Billing berpengaruh positif dan signifikan terhadap kepatuhan wajib pajak.Hal tersebut menunjukkan bahwa hipotesis kedua dalam penelitian ini diterima yaitu, $e$-Billing berpengaruh positif pada kepatuhan wajib pajak orang pribadi di Kantor Pelayanan Pajak Pratama Tabanan, artinya semakin baik penerapan e-Billing maka kepatuhan wajib pajak juga akan semakin meningkat.

Dalam model TAM digambarkan bahwa persepsi kemudahan berpengaruh terhadap sikap. Sedangkan niat merupakan suatu fungsi dasar penentu yang berhubungan dengan faktor pribadi. E-Billing akan membantu untuk meningkatkan kepatuhan wajib pajak orang pribadi di KPP Pratama Tabanan. Adanya e-Billing dapat mempermudah wajib pajak dalam proses pembayaran karena dapat menghemat waktu. Wajib pajak akan mendapatkan kode billing kemudian bisa membayar pajaknya melalui bank atau ATM dengan kode billing tersebut.

Hasil penelitian ini didukung oleh Penelitian yang dilakukan oleh Ersania \& Merkusiwati (2018) tentang pengaruh penerapan $e$-System perpajakan terhadap kepatuhan wajib pajak orang pribadi dan penelitian yang dilakukan oleh Pusparesmi (2016) yang meneliti pengaruh penggunaan system administrasi berbasis internet terhadap tingkat kepatuhan wajib pajak orang pribadi pada KPP Pratama Surakarta. Hasil penelitian tersebut menunjukkan penerapan sistem administrasi $e$-Billing berpengaruh terhadap kepatuhan wajib pajak orang pribadi. 
Ni Putu Wina Purnama Dewi dan Ni Luh Supadmi. Pengaruh ...

Variabel e-Filling memiliki nilai koefisien beta positif sebesar 0,208 dengan nilai signifikansi sebesar 0,000 . Nilai koefisien beta $>0$ dan nilai signifikansi $<0,05$ mengindikasikan bahwa e-Filling berpengaruh positif dan signifikan terhadap kepatuhan wajib pajak.Hal tersebut menunjukkan bahwa hipotesis ketiga dalam penelitian ini diterima yaitu, $e$-Filling berpengaruh positif pada kepatuhan wajib pajak orang pribadi di Kantor Pelayanan Pajak Pratama Tabanan, artinya semakin baik penerapan $e$-Filling, maka kepatuhan wajib pajak juga akan semakin meningkat.

E-Filling adalah pelaporan SPT secara online. Technology Acceptance Model beragumentasi bahwa penerimaan individu terhadap sistem teknologi informasi ditentukan oleh dua konstruk yaitu persepsi kegunaan (perceived usefulness) dan persepsi kemudahan penggunaan (perceived ease of use). Wajib pajak tidak perlu lagi melaporkan SPT secara manual ke Kantor Pelayanan Pajak karena dapat melaporkan pajaknya secara online melalui e-Filling. Adanya $e$ Filling dapat mempermudah wajib pajak dalam melaporkan SPT, maka semakin baik penerapan e-Filling semakin tinggi tingkat kepatuhan wajib pajak orang pribadi di KPP Pratama Tabanan.

Hasil penelitian ini didukung oleh penelitian yang dilakukan oleh Ersania \& Merkusiwati (2018) tentang pengaruh penerapan $e$-System perpajakan terhadap kepatuhan wajib pajak orang pribadi dan penelitian yang dilakukan oleh Putra (2015) yang meneliti tentang Pengaruh Penerapan Sistem Administrasi $e$ Registration, e-SPT, dan e-Filling terhadap Tingkat Kepatuhan Wajib Pajak. Hasil 
penelitian tersebut adalah penerapan system administrasi e-Filling mempunyai pengaruh yang signifikan terhadap tingkat kepatuhan wajib pajak.

Variabel pengetahuan perpajakan memiliki nilai koefisien beta positif sebesar 0,298 dengan nilai signifikansi sebesar 0,016. Nilai koefisien beta $>0$ dan nilai signifikansi $<0,05$ mengindikasikan bahwa pengetahuan perpajakan berpengaruh positif dan signifikan terhadap kepatuhan wajib pajak.Hal tersebut menunjukkan bahwa hipotesis pertama dalam penelitian ini diterima yaitu, pengetahuan perpajakan wajib pajak berpengaruh positif pada kepatuhan wajib pajak orang pribadi di Kantor Pelayanan Pajak Pratama Tabanan, artinya semakin baik pengetahuan perpajakan wajib pajak maka kepatuhan wajib pajak juga akan semakin meningkat.

Hasil penelitian ini mendukung teori atribusi yang menyatakan bahwa perilaku seseorang ditentukan oleh kombinasi antara kekuatan internal dan kekuatan eksternal. Pengetahuan perpajakan merupakan suatu faktor internal dari diri wajib pajak yang akan memengaruhi kepatuhan pajak wajib pajak. Pengetahuan perpajakan sangat penting dalam membantu wajib pajak dalam melaksanakan kewajiban perpajakannya. Seorang wajib pajak harus terlebih dahulu mengetahui apa yang menjadi kewajibannya. Semakin baik tingkat pengetahuan perpajakan yang dimiliki oleh wajib pajak, maka semakin tinggi kesadaran yang dimiliki wajib pajak, sehingga dapat meningkatkan kepatuhan wajib pajak dalam memenuhi kewajiban perpajakannya.

Hasil penelitian ini didukung oleh penelitian yang dilakukan oleh Kesumasari \& Suardana (2018), Palil \& Mustapha (2016), Putri \& Suandy (2015), 
Ni Putu Wina Purnama Dewi dan Ni Luh Supadmi. Pengaruh ...

dan Ulfa \& Ratnawati (2015) mengenai faktor-faktor yang mempengaruhi kepatuhan wajib pajak bahwa pengetahuan perpajakan memberikan pengaruh positif dan signifikan terhadap kepatuhan wajib pajak.

Hasil dari penelitian ini memberikan pemahaman mengenai penerapan $e$ Registration, e-Billing, e-Filling, dan pengetahuan perpajakan. Penelitian ini mendukung teori-teori yang menyatakan variabel yang digunakan dalam penelitian berpengaruh positif terhadap kepatuhan wajib pajak. Teori atribusi beragumentasi bahwa perilaku seseorang dipengaruhi oleh dua faktor yaitu faktor internal dan faktor eksternal. Faktor internal dalam penelitian ini yaitu pengetahuan perpajakan wajib pajak dan faktor eksternal yaitu e-System perpajakan mempengaruhi kepatuhan wajib pajak orang pribadi. Dalam Technology Acceptance Model terdapat persepsi kegunaan dan persepsi kemudahan. Dalam penelitian ini menjelaskan bahwa wajib pajak mempunyai kepercayaan bahwa dengan menggunakan e-system, maka akan dapat meningkatkan kinerja pengguna dan system dapat dengan mudah digunakan. Hasil penelitian menunjukkan bahwa e-Registration, e-Billing, e-Filling, dan pengetahuan perpajakan berpengaruh positif terhadap kepatuhan wajib pajak orang pribadi. Hal ini mengandung implikasi bahwa penerapan $e$-Registration, $e$ Billing, e-Filling serta pengetahuan perpajakan yang dimiliki oleh wajib pajak perlu ditingkatkan sehingga dapat meningkatkan kepatuhan wajib pajak dalam memenuhi kewajiban perpajakannya.

Bagi KPP Pratama Tabanan penelitian ini diharapkan mampu menjadi bahan evaluasi yang akan menghasilkan kebijakan-kebijakan perpajakan seperti 
meningkatkan sosialisasi terhadap penerapan $e$-System perpajakan dan menambah pengetahuan wajib pajak dengan sosialisasi peraturan perpajakan yang akan mampu meningkatkan kepatuhan wajib pajak dalam memenuhi kewajiban perpajakannya.

\section{SIMPULAN}

Penerapan e-Registration berpengaruh positif terhadap kepatuhan wajib pajak orang pribadi di KPP Pratama Tabanan, artinya semakin baik penerapan $e$ Registration, maka kepatuhan wajib pajak juga akan semakin meningkat.Penerapan e-Billing berpengaruh positif terhadap kepatuhan wajib pajak orang pribadi di KPP Pratama Tabanan, artinya semakin baik penerapan $e$ Billing, maka kepatuhan wajib pajak juga akan semakin meningkat.

Penerapan $e$-Filling berpengaruh positif terhadap kepatuhan wajib pajak orang pribadi di KPP Pratama Tabanan, artinya semakin baik penerapan e-Filling, maka kepatuhan wajib pajak juga akan semakin meningkat.Pengetahuan perpajakan wajib pajak berpengaruh positif terhadap kepatuhan wajib pajak orang pribadi di KPP Pratama Tabanan, artinya semakin baik pengetahuan perpajakan wajib pajak, maka kepatuhan wajib pajak juga akan semakin meningkat.

Bagi pihak Direktorat Jenderal Pajak dan KPP Pratama Tabanan hendaknya mensosialisasikan atau mengadakan penyuluhan secara berkesinambungan mengenai e-System perpajakan agar wajib pajak lebih memahami penting dan mudahnya menggunakan e-System perpajakan sebagai sarana dalam memenuhi kewajiban perpajakan. 
Wajib pajak orang pribadi hendaknya lebih meningkatkan kepatuhan dalam memenuhi kewajiban perpajakan karena dengan adanya $e$-System ini sudah lebih mempermudah dalam pemenuhan kewajiban perpajakan.

\section{REFERENSI}

Arum, H. (2012). Pengaruh Kesadaran Wajib Pajak, Pelayanan Fiskus, dan Sanksi Pajak terhadap Kepatuhan Wajib Pajak Orang Pribadi yang Melakukan Kegiatan Usaha dan Pekerjaan Bebas. Universitas Diponegoro.

Astuti, I. N. (2015). Analisis Penerapan E-Filing Sebagai Upaya Meningkatkan Kepatuhan Wajib Pajak Dalam Penyampaian Surat Pemberitahuan (SPT) Tahunan Pada Kantor Pelayanan Pajak Pratama Gresik Utara.

Azizah, N. (2014). Pengaruh Penerapan Teknologi Informasi (E-System) terhadap Kepatuhan Wajib Pajak pada Kantor Pelayanan Madya Malang. Universitas Islam Negeri Maulana Malik Ibrahim.

BPS. (2018, February 5). Ekonomi Indonesia Triwulan IV-2017 Tumbuh 5,19 Persen. Www.Bps.Go.Id. Retrieved from https://www.bps.go.id/pressrelease/2018/02/05/1519/ekonomi-indonesiatriwulan-iv-2017--tumbuh-5-19-persen.html

Damajanti, A., \& Karim, A. (2017). Effect of TaxnKnowledge on Individual Taxpayers Compliance. Economics \& Business Solutions Journal, 1(1), 119.

Ersania, G. A. R., \& Merkusiwati, N. K. L. A. (2018). Pengaruh Penerapan ESystem Perpajakan Terhadap Tingkat Kepatuhan Wajib Pajak Orang Pribadi. E-Jurnal Akuntansi Universitas Udayana, 22(3), 1882-1908. https://doi.org/10.24843/EJA.2018.v22.i03.p09

Fitria, V. D. (2010). Pengaruh Pengetahuan Peraturan Perpajakan, Kualitas Pelayanan, Pemeriksanaan dan Kesadaran terhadap Wajib Pajak dalam Menyampaikan Surat Pemberitahuan (SPT). Universitas Islam Negeri Syarif Hidayatullah.

Handayani, N. M. S. (2013). Pengaruh Kesadaran Wajib Pajak, Pengetahuan Perpajakan, dan Biaya Kepatuhan terhadap Kepatuhan Pelaporan Wajib Pajak Orang Pribadi di Kantor Pelayanan Pajak Pratama Denpasar Timur. Universitas Warmadewa. 
Hardiningsih, P., \& Yulianawati, N. (2011). Faktor-Faktor Yang Mempengaruhi Kemauan Membayar Pajak. Dinamika Keuangan Dan Perbankan, 3(1), 126142.

Heenkenda, S. (2016). Readiness To Retirement Planning of Estate Sector Employees In Sri Lanka. Munich Personal RePEc Archive Readiness, (72744), 1-18.

Kesumasari, N. K. I., \& Suardana, K. A. (2018). Pengaruh Pengetahuan Perpajakan, Kesadaran dan Pengetahuan Tax Amnesty Pada Kepatuhan WPOP di KPP Pratama Gianyar. E-Jurnal Akuntansi Universitas Udayana, 22(2), 1503-1529. https://doi.org/10.24843/EJA.2018.v22.i02.p25

Mahyudin, D. M. (2015). Analisis Kepatuhan Wajib Pajak Dengan Diterapkannya Program e-SPT dalam Melaporkan SPT Masa PPn Pada Kantor Pelayanan Pajak Pratama Bitung. Jurnal EMBA, 3(1), 883-890.

Mardiasmo. (2016). Perpajakan (Revisi 201). Jakarta: Andi.

Palil, M. R., \& Mustapha, A. F. (2016). Factors affecting tax compliance behaviour in self assessment system. African Journal of Business Management, 5(33). https://doi.org/10.5897/AJBM11.1742

Pratami, L. P. K. A. W., Sulindawati, N. L. G. E., \& Wahyuni, M. A. (2017). Pengaruh Penerapan e-Sistem Perpajakan terhadap Tingkat Kepatuhan Wajib Pajak Orang Pribadi dalam Membayar Pajak pada Kantor Pelayanan Pajak (KPP) Pratama Singaraja. Jurnal Ilmiah Mahasiswa Akutansi Undiksha, $7(1)$.

Pusparesmi, A. (2016). Pengaruh Penggunaan Sistem Administrasi Berbasis Internet Terhadap Tingkat Kepatuhan Wajib Pajak Orang Pribadi Pada KPP Pratama Surakarta. Universitas Islam Batik Surakarta.

Putra, T. Y. (2015). Pengaruh Penerapan Sistem Administrasi e-Registration, eSPT, Dan e-Filling Terhadap Tingkat Kepatuhan Wajib Pajak. Jurnal Mahasiswa Perpajakan, 6(1).

Putri, C. P. R., \& Suandy, E. (2015). Analisis Pengaruh Kesadaran Wajib Pajak, Pengetahuan Perpajakan, Sosialisasi Perpajakan dan Pelayanan Fiskus Terhadap Kepatuhan Wajib Pajak Hotel Melati Di Kota Yogyakarta. Jurnal Universitas Atma Jaya Yogyakarta, 1-14.

Rahayu, S. K. (2010). Perpajakan Indonesia. Yogyakarta: Graha Ilmu.

Santika, I. K. (2014). Pengaruh Kesadaran Wajib Pajak, Kualitas Pelayanan dan Sanksi Perpajakan pada Kepatuhan Wajib Pajak Air Tanah di Dinas 
Ni Putu Wina Purnama Dewi dan Ni Luh Supadmi. Pengaruh ...

Pendapatan Kota Denpasar. Universitas Udayana.

Susilawati, K. E., \& Budiartha, K. (2013). Pengaruh kesadaran wajib pajak, pengetahuan pajak, sanksi perpajakan dan akuntabilitas pelayanan publik pada kepatuhan wajib pajak kendaraan bermotor. E-Jurnal Akuntansi Universitas Udayana, 4(2), 345-357.

Syahril, F. (2013). Pengaruh Tingkat Pemahaman Wajib Pajak dan Kualitas Pelayanan Fiskus Terhadap Kepatuhan Wajib Pajak PPh Orang Pribadi. Jurnal Akuntansi, 1(2).

Ulfa, I. H., \& Ratnawati, J. (2015). Pengaruh Kesadaran, Pengetahuan Pajak dan Sikap Wajib Pajak Terhadap Kepatuhan Wajib Pajak Pekerjaan Bebas Di KPP Pratama Semarang Timur. Jurnal Akuntansi Universitas Dian Nuswantoro.

Witono, B. (2008). Pengetahuan Pajak Pada Kepatuhan Wajib Pajak. JUrnal Akuntansi Dan Keuangan, 7(2), 196-208.

www.pajak.go.id. 